\title{
Problems Existing in the Employment Guidance Teaching for College Students and the Countermeasures
}

Luyao Ma

Honghe Health Vocational College, Mengzi 661100, Yunnan, China.

Abstract: Employment guidance teaching, as an important part of higher education, is directly connected with college graduates' employment, which has an important effect on the cultivation of students' good employment concept. Based on this, on the basis of analyzing the problems in the current employment guidance teaching, this paper makes targeted explorations about how to effectively carry out employment guidance teaching for college students and puts forward the countermeasures. Keywords: College Students; Employment Guidance; Teaching Problems; The Countermeasures

The employment of college students has become one of the important issues facing our society today. With the expansion of college enrollment, the number of college graduates increases sharply every year. In recent years and a longer period of time, the economy in our country is in a new normal state. Coupled with the impact of the sudden epidemic, the employment problem of college students in our country in the next few years will become more severe. Regarding this current status, the Ministry of Education has issued a number of guidance contents, requiring to actively and effectively respond to the employment problem of college students through the efforts of all parties. Colleges and universities under the epidemic situation and the new economic normal environment. Colleges and universities, as a place for solving puzzles and teaching people to fish, are also important subjects for solving the employment problems of college students. They should also actively guide students to establish a flexible and positive employment outlook through employment guidance education and ideological and political education. Employment guidance teaching is a systematic work. In recent years, the employment problem of college students has also reflected that there are many problems in the employment guidance education of many colleges and universities, such as insufficient ideological and political education, short time for employment guidance education, and the disconnection of contents from reality. They cannot achieve the desired goals of education well. Therefore, at this stage, it is necessary to conduct a detailed and in-depth summary and analysis of past employment guidance education in colleges and universities, and then make targeted and reasonable adjustments in employment guidance teaching in order to improve employment in response to these problems and the new difficulties faced by college students in employment, so the quality of employment guidance teaching can be improved, which helps a large number of students find better employment.

\section{The problems existing in employment guidance teaching for college students}

\subsection{Schools do not pay enough attention to it, and teachers have weak knowledge}

First of all, some colleges and universities do not pay much attention to the employment guidance education, but simply set up the course, lacking system and constancy. Secondly, the employment guidance requires teachers to have a very wide career vision, and requires teachers to master rich psychology, pedagogy and background knowledge related to various

Copyright(C) 2020 Luyao Ma

doi: 10.18686/ahe.v4i10.2906

This is an open-access article distributed under the terms of the Creative Commons Attribution Non-Commercial License (http://creativecommons. org/licenses/by-nc/4.0/), which permits unrestricted non-commercial use, distribution, and reproduction in any medium, provided the original work is properly cited. 
majors. However, in fact, because some schools do not pay enough attention to this course, employment guidance teaching is formalized. Teachers are less enthusiastic about teaching due to lack of attention and supervision. For example, some teachers only carry out employment guidance according to the latest national employment policies and industry development trends, but they lack understanding and guidance on students' employment psychology, or fail to conduct in-depth analysis according to students' professional characteristics and talent needs in related industries, which cannot really help students solve the employment problem, and cannot cultivate students' correct employment outlook.

\subsection{The content of employment guidance is imperfect and unscientific}

The employment guidance teaching is a course with strong practice, but in the employment guidance teaching of some colleges and universities, the guidance content mostly focuses on employment policies, job selection skills and other aspects. The lack of job search skills and psychological guidance, and the connection between the content design and the various majors is not close enough, which leads to the problem that the employment guidance is too general and lacks pertinence. Even the employment guidance of some colleges and universities uses a multi-class public course teaching method from beginning to end, lacking distinct guidance for different majors, and failing to increase effective and sufficient practical guidance on the basis of theoretical guidance, which is very unscientific. In addition, some teachers overemphasize the seriousness of the current employment situation in employment guidance and over encourage students to lower their career choice expectations, but they neglect the investigation of college students' employment psychology or fail to effectively connect with career planning education, finally resulting in poor quality of the employment guidance teaching.

\subsection{Employment guidance objectives are vague, and methods are backward}

First of all, many college managers do not have a thorough understanding of the role of employment guidance teaching, believing that employment guidance teaching is only to help students succeed in employment, and to complete the corresponding employment rate of college students. However, they do not know that employment guidance is closely related to professional teaching, career planning and the future career development of students. Under the guidance of this recognition, it is easy to result in employment guidance teaching lacking systematic goals, and problems such as despising education and emphasizing services. The goal is ambiguous and the positioning is confusing, which leads to the unscientific content of employment guidance teaching, failing to effectively solve some misunderstandings in college students' career selection, resulting in many students being unemployed after graduation, or being difficult to deal with complex jobs and job competition. Secondly, the method of employment guidance is backward. The employment guidance in many colleges and universities only has narrative classroom teaching. Besides, the class is conducted in the form of open classes, which mainly reflects in the aspect that the teaching format is mainly cramming. It is difficult to effectively carry out practical teaching and discussion as well as interaction, resulting in the neglection of the subjectivity of some students. Finally, some colleges and universities cannot make good use of the school website and employment guidance office to perform effective publicity and guidance, resulting in students being unable to obtain useful guidance information and effective after-school guidance.

\section{The countermeasures to solve the problems of the employment guidance teaching for college students}

\subsection{Strengthen the construction of teachers}

Establishing a high-quality and professional employment guidance team is the first aspect that many colleges and universities need to improve, and is also the primary way to quickly improve the quality of college employment guidance. First of all, colleges and universities should select teachers of employment guidance teaching with high standards and require the instructors have a wide range of professional knowledge, rich knowledge and teaching skills in education, psychology, society and other disciplines to ensure that they can provide full and comprehensive employment guidance for graduates of different majors, and have the ability to develop personalized consulting services. Secondly, senior human resource management personnel in major-related industries can be employed to assist in teaching. They can analyze the employment problems of college students from the aspects of industry needs, and provide accurate guidance, allowing graduates to have more correct and clear understanding on the employment status and professional work of the major and industry, so as to help them search 
jobs and get employment through targeted practice and learning according to career planning. Finally, it is necessary to establish a scientific and effective supervision evaluation mechanism to promote the guidance teachers to be more active and proactive in improving their own knowledge and teaching ability, and to encourage teachers to continuously optimize teaching methods and teaching models through the fair rules of survival of the fittest.

\subsection{Scientifically design the guidance content}

Colleges and universities should strengthen the pertinence of the content of employment guidance, take the needs of students as the foundation, and more closely link majors of students in the design of contents, and fully consider students' psychology of employment and employability through related teaching contents, such as career planning and ideology and politics, so as to achieve a more ideal teaching effect. First of all, it is necessary to strengthen ideological guidance, that is, reestablish and reshape students' three views and employment views in combination with the content of employment guidance, guiding contemporary college students to effectively choose information, accurately understand themselves and the work, and establish a flexible and scientific employment concept. Secondly, it is necessary to strengthen the psychological education of students in the employment guidance teaching, guiding students to form a healthy employment psychology, improving their ability to resist stress, and helping them develop mental qualities such as hard work, so as to enable college students to actively adapt to the change of the identity, role and environment. Finally, it is necessary to strengthen the cultivation of the guidance of students' comprehensive literacy and guide students to pay more attention to the training of their own practical ability and thinking ability.

\subsection{Accurately locate the goals of guidance and optimize the method of guidance}

While expanding enrollment, colleges and universities should make more detailed and in-depth professional investigations, on the basis of which, clarifying the goals and tasks of training plans of professional talents and employment guidance. First of all, it is necessary to pay attention to employment guidance teaching, and take employment guidance teaching as the current important work of colleges and universities to alleviate current employment pressure of students. According to the guidance of the Ministry of Education, it is necessary to make the employment guidance teaching a regular and systematic process. Secondly, the leadership of the supervision and management of colleges should be strengthened to ensure the systemic, effective and constant development of the employment guidance teaching. Finally, it is necessary to improve the method and the quality of the employment guidance, increase students' cognition and interest in occupations through more practical teaching, and guide students to actively conduct social surveys through task teaching, so as to more clearly understand and adjust their own career planning, and encourage them to have more contact and understanding of the society. They can also give precise guidance to students of different majors or individual students through small class teaching and other forms.

\section{Conclusion}

In summary, the higher education in our country has developed rapidly in recent years, and the number of graduates has increased significantly year by year. However, the corresponding security system and social development status are not enough to support the huge employment demand. In addition, there are large differences between the actual ability of many students and their expected work, which leads to the employment problem of college students being very serious in recent years. Universities should analyze their own problems in depth, and then improve the pertinence and quality of employment guidance teaching starting from the aspects of accurate positioning, optimizing the guidance content, and strengthening practical teaching, so as to solve the employment problems of college students in a practical and effective way.

\section{References}

1. Nurzati E. Problems and reform exploration of employment guidance courses for college students. Contemporary Educational Practice and Teaching Research 2018; (09): 622-625.

2. Zhang SH. Analysis of problems existing in employment guidance for college students in private colleges and countermeasures research. Higher Education 2017; (11): 247-249.

3. Dou GZ. Research on problems and countermeasures of current career planning and employment guidance courses for college students. Science and Education Guide (Electronic Edition) 2018; (11): 61-62. 